\title{
De algunos usos de la fotografía en la literatura hispanoamericana contemporánea
}

\author{
On Some Uses of Photography in Contemporary Spanish-American Literature \\ De alguns usos da fotografia na literatura hispano-americana contemporânea
}

\section{Florence Olivier}

UNIVERSITÉ SORBONNE NOUVELLE, FRANCIA

Catedrática (Professeur des Universités) en Université Sorbonne Nouvelle

Paris 3 , Francia. Habilitation à diriger des recherches: "Ecritures

et discours dans la littérature mexicaine du XXe siècle", Université

Sorbonne Nouvelle Paris 3 (2002). Principales publicaciones: Carlos

Fuentes o la imaginación del otro (Editorial de la Universidad

Veracruzana, 2007), Carlos Fuentes ou l'imagination de l'autre (Aden, Coll. Parcours, 2009), y editora de Exils, migrations, création. Vol. IV.

Etudes Romanes (Indigo, 2008), Cultures en conflits, Cultures et conflits

(en colaboración con Valérie Peyronel) (Michel Houdiard, 2009), La littérature latino-américaine au seuil du XXIe siècle. Un parnasse

éclaté (en colaboración con Françoise Moulin-Civil y Teresa Orecchia-

Havas) (Aden, 2013). Correo electrónico: flordolivo@wanadoo.fr

Artículo de reflexión

Documento accesible en línea desde la siguiente dirección: http://revistas.javeriana.edu.co 


\section{Resumen}

A la hora de la

desmaterialización de la imagen fotográfica digital, ¿cómo y con qué renovados propósitos insertan fotografías impresas en sus ficciones y ensayos ciertos escritores latinoamericanos? Como breve muestrario de algunos usos de la fotografía en la actual literatura hispanoamericana, se aborda en este artículo la porosa frontera entre documentación y construcción ficcional, en especial el irónico cuestionamiento de la identidad del autor, en obras de Alan Pauls, Jorge Volpi y Mario Bellatin.

Palabras clave: fotografía; simulacro; autoficción; autobiografía apócrifa

\section{Abstract}

In times of the digital dematerialization of the photographic image, how and to what purpose are present Latin American authors inserting printed photographs in their essays and fictions? A brief survey into the uses of photography in Latin American literature, the present contribution examines the hazy borderline between documentation and fictionalization, and particularly the ironic call into question of the author's identity, in works by Alan Pauls, Jorge Volpi and Mario Bellatin.

Keywords: photography; simulacra; autobiographical fiction; auto-fiction

\section{Resumo}

Na hora da desmaterialização da imagem fotográfica digital, como e com quais renovados propósitos inserem-se fotografias impressas nas suas ficções e ensaios certos escritores latino-americanos? Como breve mostruário de alguns usos da fotografia na atual literatura hispano-americana, neste artigo aborda-se a porosa fronteira entre documentação e construção ficcional, em especial o irónico questionamento da identidade do autor, em obras de Alan Pauls, Jorge Volpi e Mario Bellatin.

Palavras-chave: fotografia; simulacro; autoficção; autobiografia apócrifa

\section{Cómo citar este artículo:}

Olivier, Florence. "De algunos usos de la fotografía en la literatura hispanoamericana contemporánea". Cuadernos de Literatura 20.40 (2016): 430-448. http://dx.doi.org/10.11144/Javeriana.c120-40.aflh 
EN LOS ÚLTIM OS veinte años, las variadas y nada nuevas interacciones entre fotografía y literatura han dado lugar a una profusión de estudios que examinan casos que, no por ser muy disímiles, dejan de verse reunidos bajo la general denominación de fotoliteratura. Entre tantas relaciones y realizaciones híbridas, abstracción hecha de la tradición documental realista o colaboración entre escritores y fotógrafos en torno a realidades referenciales, suele distinguirse entre la ilustración, en el sentido más literal del término, o sea, la efectiva inserción de reproducciones fotográficas entre las páginas de un libro que puede o no ser de ficción y las muy variadas formas de presencia-ausencia de la fotografía en un relato de ficción o un ensayo, vierta este o no sobre sobre la propia fotografía. En efecto, se analiza de modo recurrente la notoria influencia del encuadre fotográfico en los modos narrativos, sobre todo a partir de la segunda mitad del siglo XX, y asimismo, la elaboración de un relato a partir de una foto no reproducida y, en ocasiones, imaginaria. ${ }^{1}$

A la hora de la desmaterialización de la imagen fotográfica digital que no requiere su impresión para circular por la red y ser contemplada, siquiera fugazmente, en cualquier punto del mundo globalizado, se advierte que, paradójicamente, varios escritores, entre estos, algunos hispanoamericanos y, tras ellos,

1 Como muestrario de la diversidad de tales estudios, cito algunos, publicados en Francia, donde las investigaciones sobre la llamada fotoliteratura acusan, a decir de un especialista como Paul Edwards, cierto retraso respecto de los países anglosajones aunque privilegian mucho menos la tradición documental. Así, Soleil noir. Photographie et littérature, del mismo Paul Edwards, emprende, desde una perspectiva histórica y en torno a un corpus franco-británico, una clasificación de tales interacciones, con excepción de la tradición documental, desde la aparición del daguerrotipo hasta el surrealismo. Esta suma se interesa en la vertiente de la fotoliteratura que el autor denomina imaginaria, aquella que de uno u otro modo se ve ligada a la ficción, la cual, no se descarta, puede obedecer a un propósito realista. Un número de la revista Études Romanesques, dedicado a "la fotografía y lo novelesco", propone plurales intentos de teorización a partir del análisis de distintas obras literarias francesas o de los discursos y posturas de varios escritores sobre la fotografía desde su nacimiento. Portraits de l'écrivain contemporain, volumen colectivo publicado tras un encuentro literario dedicado al tema en la Villa Gillet, reúne reflexiones de escritores, críticos y fotógrafos en torno a los alcances sociológicos, comerciales, semióticos, estéticos, de ese objeto particular que es el retrato de autor. "Le défi de l'incomparable. Pour une étude des relations entre littérature et photographie", artículo reciente del comparatista francés Michel Collomb, elabora una doble síntesis acerca, por una parte, de las prácticas históricas y contemporáneas de dichas interacciones por parte de los escritores o los artistas fotógrafos o plásticos y, por la otra, aunque en menor medida, en torno a los estudios que se han dedicado a tales relaciones. El autor concluye su ensayo con el anuncio de nuevos desarrollos en estas relaciones a favor del auge de la fotografía numérica, subrayando que, desde su aparición, "la fotografía jamás ha dejado de ser a la vez un agente propagador y el campo de experimentación de una estética moderna fundada en las mezclas y las interacciones entre áreas de expresión" (Collomb 8; mi traducción). 
sus editores, acuden a la impresión de fotos entre las páginas de sus ficciones o ensayos con vertientes autobiográficas o, en ocasiones, como anexo, apéndice o apostilla visual. Como en el siglo pasado, parecería, el objeto libro encierra reproducciones fotográficas que, junto con el texto impreso, colaborando de forma consonante o disonante con lo narrado o enunciado, pretenden brindar el acceso a universos distantes o, por lo menos, ajenos a la directa e inmediata experiencia del lector. Los mencionados estudios de fotoliteratura hacen hincapié en los contradictorios y, en ocasiones, ambivalentes usos de la fotografía impresa en los relatos y ensayos literarios a lo largo de dos siglos de historia literaria. Inquietante icono de valor simbolista, fantástico en ocasiones, o resorte de un efecto de realidad que apuntala el código realista de una historia narrada; registro de la otrora presencia material de elementos que pueden verse intencionadamente reunidos y escenificados o tan solo elegidos en la realidad y, por ende, dispuestos al cabo por la mirada del fotógrafo; simulacro y huella de una presencia; privilegiado indicio de la hibridez entre objetividad y subjetividad, la fotografía desempeña papeles muy diversos en el caso de su reproducción en el texto literario. ¿Cómo?, ¿con qué renovados o nuevos propósitos se maneja en la actualidad de la literatura hispanoamericana la reproducción e inserción de fotografías en textos de relatos y ensayos?

Como breve muestrario de algunos usos de la fotografía impresa en la actual literatura hispanoamericana, nos interesaremos en la forma en que algunas fotos de familia escanden el barthesiano ensayo de Alan Pauls La vida descalzo (2006), al recurrir a una variante tenue del manejo del retrato de autor como accesorio de la autobiografía; en el montaje de la foto del autor que, en la contraportada del libro, cita la de otro autor, solarizada esta en la portada, como complemento visual de las estrategias de la ficción en A pesar del oscuro silencio de Jorge Volpi (1992); en la escansión del relato-confesión del narrador por unas fotos de prensa históricas completadas por ficccionalizadas fotos de familia en la novela Memorial del engaño (2014) de Volpi y, de nuevo, en el ficticio retrato del a medias ficticio autor que aparece en la solapa del libro; en la foto como seudodocumento en Shiki Nagaoka: una nariz de ficción (2001), fragmentaria biografía de un ficticio escritor japonés, o como declarada instalación en Perros héroes (2006), novelas, ambas, de Mario Bellatin.

Desde luego, si bien, en las obras de Alan Pauls, Jorge Volpi y Mario Bellatin, que acuden a la impresión de fotos, siempre crean los usos de la fotografía un entredós estético y semántico entre lo legible y lo visible, se corresponden con la pertenencia de los mismos textos a la ficción o a la no ficción y con su particular inscripción en un género literario. Las fotos de La vida descalzo, de 
Pauls, ensayo sobre las mitologías de la playa hibridado con un discurso autobiográfico, parecerían en un inicio apuntar a certificar, según la famosa formulación de Barthes en La chambre claire que "aquello que se ve fue", desde el manejo de esa documentación íntima y privada que es el álbum de familia, aunque solo se señala furtivamente la procedencia de las fotos. En las novelas de Volpi y Bellatin, las fotos participan del discurso de la ficción: estén o no distribuidas entre las páginas del texto, acaban formando parte integrante del relato visual-textual, inscribiéndose en una compleja relación con la tradición documental de la ilustración fotográfica que cuestionan e invierten con sendas estrategias. Las dos obras de Volpi descontextualizan y recontextualizan en aras de la ficción, en las portadas o el relato novelesco, documentos fotográficos de archivos públicos y privados, resueltamente convertidos en apócrifos en Memorial del engaño.

El uso de los conjuntos fotográficos en las dos novelas de Bellatin difiere de una a otra: apócrifamente documental en Shiki Nagaoka, artístico e inconfesadamente documental en Perros héroes, puesto que las fotos resultan del registro de supuestas creaciones artísticas relacionadas con el universo de la ficción. Sin embargo, también en Shiki Nagaoka se ve subrepticiamente reivindicado algún gesto artístico, al acreditarse a la fotógrafa Ximena Berecochea como responsable del trabajo de rescate de los pretendidos "Documentos fotográficos sobre Shiki Nagaoka". Reunidas y presentadas, entre otros anexos, en un portafolio, estas fotos pueden ser, en algunos casos, documentos desviados de su identidad original y, en otros, creaciones de la propia Ximena Berecochea o de otro fotógrafo. El diseño del llamado "folleto de instalaciones" de Perros héroes, editado como separata, se acredita al artista plástico Aldo Chaparro, mientras el fotógrafo que registró las instalaciones no es sino Mario Bellatin, que también es acreditado como autor de la foto de la portada. Anteceden el relato, en una correlación de recíproco comentario, un dibujo sin firma, en la página 7 y, en la 9, una foto cuyos elementos reproduce el dibujo desde otro ángulo, misma de la que un detalle hace las veces de portada del folleto. Volveremos sobre los alcances de semejante composición y, en rigor, instalación de las fotos y el dibujo en el libro.

\section{Hacia la ficción: ensayo autobiográfico y álbum familiar}

Por su mismo género híbrido de ensayo autobiográfico, La vida descalzo parecería invitar a una lectura llana, como si se tratara de simples ilustraciones, de las fotos de infancia que, se induce, son las del autor, en un periodo de su vida referido una y otra vez en el texto y escandido por anuales estancias veraniegas en la playa. Solo que, como lo señaló Gersende Camenen ("Photographie"), el que estas nueve fotos no estén referenciadas ni comentadas en el texto perturba 
y diversifica su función, que no resulta documental e ilustrativa, sino más bien sugestiva. Si, por ello, producen un primer efecto rítmico al puntuar los segmentos del texto y, sesgadamente, los temas de reflexión abordados en estos, ya que en ocasiones guardan una sutil relación temática con lo enunciado, lo hacen a modo de colofón o de introducción visuales y convidan a una ensoñadora, casi indolente, lectura del libro como álbum hojeado por el lector. Al ventilar la lectura, que puede interrumpirse en las pausas brindadas por las imágenes, las fotos deparan esa privilegiada sensación de contemplativo ocio que se asocia con el estar en la playa al tiempo que el ir y venir entre foto y texto declina de otro modo el curso asociativo y sinuoso de las reflexiones que surgen a lo largo de la meditación del ensayista. El lector parecería así repetir la inicial contemplación de esas fotos íntimas por parte del autor que las seleccionó y las distribuyó por el texto, duplicando por un efecto de distanciación visual la discontinuidad temporal entre el yo del ensayista e intermitente autobiógrafo y el él de aquel niño que fue. Las fotos, aisladas en páginas desprovistas de texto, reproducidas casi en su centro en un tamaño reducido, muestran a un niño rubio que, a veces, juega con otro, muy parecido al primero. El efecto visual de la proporción entre la página y la foto impresa en ella crea de nuevo una distancia, ya que el o los sujetos retratados se ven así mantenidos en una lejanía espacial respecto de la mirada del lector, fijados en la diminuta imagen en el entorno de una playa tan anónima que se presta al recuerdo genérico de toda estancia infantil en la playa.

Los temas y motivos del ensayo, tejidos con las evocaciones autobiográficas, también se antojan diversa y divertidamente interpretados, más que traducidos, por las fotos en el lenguaje común de las experiencias infantiles, aquellas que, para el autor, antecedieron toda conceptualización pero de cuyo recuerdo parece abrevarse la reflexión: a la playa como desnudez, tan vacía de imágenes que apela al otro escenario de las imágenes oníricas y cinematográficas, parece hacer eco alguna foto donde se advierte tras el niño la vastedad del espacio arenoso (19, 29); a la playa de los atletas y los guerreros, las fotos de los niños que juegan a la pelea $(51,83)$, o la del niño sosteniendo un palo (41); al, no menos común por acentuadamente personal, incidente de la enfermedad que veda los placeres de la playa, al cabo felizmente sustituidos por el de la lectura, la foto del niño acostado en su cama algún día de intenso calor (113). Solo que esta última imagen anuncia y propicia el vuelco genérico que da el texto al pasar del discurso autobiográfico/ ensayístico a la casi ficción narrada en tercera persona, como lo muestra con gran claridad el estudio de Gersende Camenen, que subraya el "fuerte eco proustiano" ("Photographie" 225) del fragmento. En efecto, la escena en que el ahora personaje, aquel "chico de diez u once años", ya crecido, (Pauls 120), descubre en 
la lectura el acceso a las ilimitadas posibilidades del verdadero otro lugar, que no es visual -ni envés cinematográfico u onírico de la playa, ni natural como esta-, augura el ulterior descubrimiento de la escritura y, desde luego, la de este texto.

En todo caso, la serie de fotos, registro de la experiencia de vida del autor y probable semilla o tan solo auxilio de sus reflexiones sobre la playa, induce un vaivén entre texto e imagen al hilo de la lectura del libro, vaivén que, a su vez, permite acentuar otro, textual, entre distintas figuras y posturas del enunciador y entre distintas vertientes genéricas del libro. El discurso oscila entre el yo del presente y el yo/él del pasado, en la componente autobiográfica; entre el yo del autobiógrafo y el yo del ensayista, que se nutren el uno del otro, vaivén, este, tan barthesiano y tan propio del género polimorfo del ensayo. In fine asoma el novelista. Si el ensayo autobiográfico juega con la confidencia que ofrece al lector ciertas experiencias infantiles y adultas como experiencias compartibles, y si, por otro lado, juega con la profesión de fe del autor que afirma sus propios gustos y sus juicios personales sobre las mitologías contemporáneas de la playa, la serie de fotos sostiene de alguna manera un relato latente. Este relato que se vuelve manifiesto y novelesco desde la asociación narrativa entre la novena y última foto y el último fragmento textual, propone una reflexión sobre las distintas incitaciones, visuales y textuales, al ejercicio y al placer de la imaginación. En esta personal y a la vez ejemplar historia, termina privilegiada entre todas, la del libro, que, desde la calculada trampa de ficción que le tiende, despierta y encauza la imaginación del lector. Así, la playa, que de noche estimula la pantalla onírica en que se proyectan los sueños cual películas, la playa, tan filmada en películas que recuerda el ensayista, la playa épica o erótica o turística se convierte metafórica y metonímicamente en su otro ser, la recogida e íntima playa de la lectura, adonde nos conduce con sucesivos rodeos y vaivenes el ensayo y relato texto-visual de La vida descalzo.

Última observación: el manejo de las fotos de infancia de Alan Pauls logra poner en vilo, por su pudor referencial, por su anónima autoría y su factura sin duda familiar, por la invitación a verse como otro que formulan, cualquier uso fetichista o mercantil de la foto de autor.

\section{¿Quién es quién? Biografía novelada de escritor, citas textuales y cita fotográfica}

De un peculiar uso de la foto de autor más comúnmente puesta a circular con el libro, la del llamado frontispicio o la de la solapa o la de la contraportada, se trata en A pesar del oscuro silencio de Jorge Volpi, primera novela del escritor mexicano que, en 1992, aún firmaba con sus dos apellidos: Jorge Volpi Escalante. Solo dos 
fotos aparecen en ese delgado volumen, en sendos espacios paratextuales. La portada ostenta en la casi totalidad de su formato un conocido retrato en blanco y negro del poeta Jorge Cuesta, y, en la contraportada, aparece, en un formato mucho más reducido, el retrato en blanco y negro del autor, Jorge Volpi Escalante, cuya pose repite hasta el menor detalle la de Cuesta en la fotografía del frontispicio. Notaremos de paso que semejante distribución de las imágenes induce una manipulación del objeto libro, ya que el lector o simplemente el comprador, una vez advertida las semejanzas entre las dos fotos, se verá incitado a darle vuelta al volumen una y otra vez. El uso de una apócrifa foto de autor impresa en un libro en aras de la ficción forma parte de cierta tradición literaria; tampoco resultan escasas las fotos trucadas del autor en novelas que pretenden dar por auténticas las peripecias narradas en el relato. Solo que, en este preciso caso, el manejo de los dos retratos en el paratexto obedece a una estrategia a la que recurre amplia y diversamente el texto de la ficción en $A$ pesar del oscuro silencio: la de la cita, que se transpone con aparente facilidad y cierto refinamiento a los códigos técnicosemánticos del médium fotográfico.

El texto, en efecto, asocia las escrituras y los textos de Cuesta, inicialmente privados como la correspondencia o públicos y publicados como ciertos fragmentos de poemas, a la escritura y al texto de Jorge Volpi, en un intenso despliegue de regímenes y prácticas de la cita, parcialmente referenciada en un anexo, que sirve los alcances simbólicos de la historia narrada en la fábula. Fascinado por el pulcro hermetismo de la obra poética de Cuesta y por la lúcida exigencia de su obra crítica, aunque no menos por la figura y el trágico destino del poeta, quien, acosado por una paranoia e internado en dos ocasiones en un siquiátrico, terminó emasculándose y suicidándose, el narrador, Jorge su nombre, emprende una investigación biográfica y crítica sobre la vida y la obra del escritor. Estructurado en tres "libros", el relato alterna la narración en primera persona del narrador con la de la vida de Jorge Cuesta, narrada en tercera persona, estableciendo un efecto de esperpéntico espejo entre los destinos del poeta y de su crítico y biógrafo. Así, entre otros ejemplos, la conflictiva relación que este mantiene con Alma, su amante, se convierte en paródica y hasta grotesca repetición de aquella que desunía a Jorge Cuesta y a su esposa Lupe Marín. Cada vez más poseído por el destino de su objeto de estudio, el narrador vive o cree vivir las experiencias a las que se sometió Cuesta en cuerpo propio. Si la búsqueda de Cuesta asociaba el fantaseado propósito de alcanzar la androginia corporal al proyecto de llegar a dominar el tiempo - es decir, a salirse de él, en cuerpo y escritura-, Jorge se entrega a una grotesca sesión de maquillaje como travestí con ayuda de los cosméticos de su compañera. En esta fábula que alegoriza la involuntaria imitación, 
la confusión entre identidades de autor y al cabo la "angustia de influencia"; se trata allí para el biógrafo, más que del intento de convertirse en andrógino, del loco deseo de igualar al poeta convirtiéndose en él. Pero lo suyo no resulta más que mascarada.

La identidad entre los nombres del autor, del narrador y del poeta biografiado desestabiliza la identidad de la voz narrativa y crea, mediante la inserción de datos referenciales relativos a Jorge Volpi, un efecto de autoficción. A este narrador se atribuye en efecto el ensayo "El magisterio de Jorge Cuesta", publicado por Jorge Volpi en 1991 y merecedor del Premio Plural del Ensayo, cuya introducción se ve parcialmente citada en el relato, a la par que otras fuentes críticas. $\mathrm{Si}$, por un lado, el minucioso trabajo de enmarañamiento del régimen de la cita entre textos autógrafos y textos allógrafos contribuye a confundirlos; por otro, los argumentos, inicialmente diferenciados, de la vida de Cuesta y la del narrador también tienden a confundirse textualmente gracias a una suerte de balbuceo o autocita del texto novelesco, al repetirse, aunque con alterada enunciación, fragmentos casi idénticos al inicio y al final del libro. En su primera aparición, narran en tercera persona los momentos previos a la última hospitalización siquiátrica de Cuesta y su posterior suicidio; en el desenlace se repiten en primera persona en un primer episodio que escenifica el fallido intento del narrador de imitar a su modelo y en la ambigua y abierta escena final donde pareciera disponer su propio y deslucido suicidio. Si la fábula vierte sobre la relación crítica y la autoría al narrar en clave fantástica y grotesca la identificación del biógrafo al biografiado, o sea la del investigador, novel escritor, a su objeto de estudio, autor de culto, no cuestiona menos el manido gesto crítico que pretende interpretar la obra de un autor a la luz de su vida ni la trágica confusión de Cuesta entre su cuerpo y su escritura. Para ello, escenifica episodios en torno a la cuestión de la identidad sexual que atormentaba al poeta. De hecho, en un registro metaliterario, $A$ pesar del oscuro silencio narra otro pasaje, no aquel que llevaría de lo masculino a lo andrógino, tampoco aquel que llevaría del tiempo ordinario de los mortales al tiempo absoluto, ni siquiera aquel que metamorfosearía al personaje del crítico en el del poeta que lo habita, sino el paso de la identidad de ensayista de Jorge Volpi a la del novelista en que se convierte al escribir este libro. Así, tanto el tema de la posesión como su manejo por los recursos del argumento corroboran o ilustran irónicamente en el relato la progresiva intrincación entre los escritos y las experiencias del narrador y del poeta Cuesta, en una fábula que, si bien parece exorcizar la angustia de influencia, señala el paso de la escritura crítica sobre la obra de otro autor a la escritura de la obra propia, triunfadora ficción. 
Fábula metaliteraria, A pesar del oscuro silencio aún sostiene a modo de ensayo un discurso sobre la vida y la obra de Jorge Cuesta, aunque juega con los recursos y las libertades propias de la ficción. El trabajo sobre los modos de enunciación aunado al sutil y múltiple trabajo sobre el régimen de la cita alegoriza el entredós entre la glosa y la invención, mientras la ficción permite interpretar el trágico derrotero de la búsqueda de Cuesta en torno a la identidad y al tiempo, llegado el momento en que el poeta, al ya no poder restringirla a su elaboración en la poesía, le sacrificó verdaderamente su sexo y su vida.

En la edición de Joaquín Mortiz, los retratos fotográficos de Jorge Cuesta y de Jorge Volpi desempeñan un papel ciertamente auxiliar pero significativo en la alegorización novelesca de la relación crítica como experiencia de posesión. Solarizada y objeto de un montaje, la foto original de Cuesta, tomada por Manuel Álvarez Bravo, ya se ve citada en la imagen de la portada. Al ser recortada, la figura del poeta, que se confunde parcialmente a lo Magritte con un fondo nuboso de matices grises, sugiere a la vez el desdibujamiento y la presencia de Cuesta en una memoria literaria que redujo su imagen a unos rasgos biográficos excesivamente marcados. La foto sin solarizar de Jorge Volpi, cuya silueta se recorta sin confusión alguna sobre un fondo de matices asimismo grises, obedece en su forma a las convenciones del retrato fotográfico de los años treinta y cuarenta. Si en coherencia con la ficción novelesca, de la que participa y que desborda, representa al autor del libro como seudorreencarnación o simple imitador del fantasmal, Cuesta, al citar en un segundo grado un retrato tan famoso como el que le sacara Manuel Álvarez Bravo al poeta del grupo de los Contemporáneos, sitúa al joven y nuevo novelista en un modesto aunque seguro lugar en la tradición literaria y el mundo artístico mexicanos.

\section{Autobiografía apócrifa y archivo fotográfico documental}

La obra de ficción de Jorge Volpi que ha ido creciendo entre 1992 y 2014 con la publicación de voluminosas y alguna que otra breve novela, no había vuelto a recurrir al manejo ficcional de la fotografía hasta Memorial del engaño. En esta ficción, la más reciente publicada por el autor, se modifican la amplitud, la intencionalidad y los efectos de tal uso. Thriller que narra, a modo de ficticio relato autobiográfico, la vida y las obras de un financista neoyorkino llamado J. Volpi, la novela se inscribe, por su factura marcadamente satírica y la profusa documentación en que se funda el marco referencial del argumento, en la serie de obras del mexicano que escenifican e interrogan la historia política y la cultura contemporáneas desde la época de la segunda guerra mundial. En Memorial del engaño, J. Volpi, pícaro global cuyo relato se presenta como la desfachatada confesión de cómo llegó a ser 
uno de los impunes responsables de la magna crisis financiera en Wall Street de 2008 que vio, entre otras espectaculares caídas, la del banco Lehman Brothers, también refiere su historia familiar. Lejos de pertenecer al exclusivo ámbito de la vida privada, la historia de sus padres se vincula con las redes de espías comunistas que, según el House Un-american Activities Committee, operaban entre los más altos funcionarios del Tesoro estadounidense en los albores de la Guerra Fría. Así, el doble argumento refiere dos periodos de la historia económica mundial: 1) el de los años noventa y la primera década de este siglo y 2) el de la inmediata posguerra que vio la fundación del Fondo Monetario Internacional. A lo largo de veinte años de arduas pesquisas sobre su difunto padre Noah Volpi, el narrador corrobora que su progenitor estuvo implicado en las actividades de los funcionarios procesados por antiamericanismo y espionaje a cuenta de la Unión soviética, acusaciones que no juzga infundadas. Al completarse con la trama de espionaje el relato de las aventuradas peripecias de la especulación financiera internacional en los la primera década del siglo XXI, la versión de J. Volpi crea una filiación histórica entre el pronto desvirtuarse del proyecto de regulación económica controlada por los Estados, en aras de una justa distribución de capitales entre las naciones de la posguerra, y la vertiginosa actividad financiera global propiciada por el neoliberalismo. Moralmente equiparadas por la cínica visión del narrador, la regulación económica y el liberalismo, la planificada economía capitalista y la doctrina neoliberal, solo parecen triunfar los falsarios y pícaros de envergadura, cual ese J. Volpi.

Al asimilar la especulación financiera a una gigantesca estafa, la parte contemporánea del argumento insiste, una y otra vez, no solo en la desmaterialización del dinero de los pequeños o grandes inversores en los hedge funds, sino en su total desaparición o volatilización a favor de los sucesivos manejos de valores de riesgo asociados a las opciones y los derivados financieros. El estafador J. Volpi acaba, al igual que su señalado antecesor de los años veinte - Charles Ponzi, aunque en una escala mucho mayor-, vendiendo el equivalente a bonos que no encubren más que vacío.

Desde luego, la primera estrategia novelesca que atribuye a J. Volpi la autoria del libro participa de la gran variedad de recursos ficcionales y metaficcionales que, en el relato, sirven el tema de la estafa, el engaño, la falsificación. Si así se ostenta el carácter fake del apócrifo libro, firmado en la portada por J. Volpi, el efecto de falsificación se encarece aún con la fotografía de autor de la solapa, imagen en blanco y negro que connota caricaturescamente la clandestinidad del prófugo al tornarse indiscernibles, mediante un contraluz, los rasgos de un torso y un rostro vistos de perfil sobre un fondo de espléndido y nuboso atardecer. La 
intencionada mala calidad de la fotografía remite desde luego al estilo de ciertas fotos de la prensa especializada en suscitar y explotar escándalos y en fabricar noticias sobre supuestos fenómenos parananormales o sobrenaturales. Se advierte en este doble manejo del nombre y la foto del autor un primer gesto paródico, al imitarse la fabricación mediática de la noticia, a la vez que una nueva variante y desarrollo de las estrategias caras a las novelas de la Trilogía del Siglo XX, de Jorge Volpi. Sosteniéndose en un difícil equilibrio entre su ambición reflexiva, su calculada composición y su ejercicio paródico de los recursos propios de las novelas de género, estas novelas cuestionan las relaciones entre poder político y saber científico o entre teoría y práctica de la filosofía política, la semiología, el sicoanálisis. No poco contribuyen sus mentirosos narradores al examen satírico de la historia contemporánea mediante relatos cuyos embustes también sirven a los efectos lúdicos de la ficción: el estafador J. Volpi se hermana así con el criminal científico nazi y supuesto autor del texto de la novela política policial En busca de Klingsor, y con el pícaro intelectual mexicano, imitador de los autores franceses del llamado pensamiento 68 en El fin de la locura.

Como estas novelas posmodernas, Memorial del engaño recurre a juegos especulares entre sus tramas, a sucesivas y contradictorias versiones de las peripecias vividas por los personajes, a un manejo del tiempo del relato mediante analepsis y prolepsis que favorecen el suspense, las hipótesis y los desmentidos de una larga pesquisa, a una composición imitativa: aquí se remeda la de una ópera. A todo ello, se agrega el manejo de las veinte fotografías insertas en el relato, amén de la del autor apócrifo, a modo de ilustración documental y seudopruebas del carácter verídico de lo narrado. Procedentes del álbum familiar de Jorge Volpi, en el caso de las fotos ligadas a la historia familiar del protagonista y, en el de las fotos vinculadas a los procesos por espionaje en contra de funcionarios norteamericanos, casi todas auténticas fotos de la prensa de la época recogidas en el archivo Getty Images, fácil e inmediatamente asequibles ahora en la red, estas imágenes constituyen un acervo documental de origen híbrido y ambivalentes efectos. El archivo privado del auténtico autor se ficcionaliza, y al combinarse con documentos fotográficos de amplia difusión, los contamina, pues les otorga un valor ficticio o subraya, por lo menos, la poca fiabilidad de la imagen de prensa que pretende apuntalar, cuando no certificar, la verdad del discurso que ilustra. El efecto de contagio resulta más eficaz, por cuanto alguna foto de origen privado entra en la serie de las fotos que ilustran la trama de espionaje y se crea así una confusión entre las de una y otra procedencia. Se duplica de este modo el efecto surtido por las intersecciones textuales entre los argumentos de la historia privada y la pública de las dos generaciones de ficticios Volpi. 
Así, las fotos terminan cobrando una doble función narrativa y ficcional al vincular visualmente, por un lado, los elementos históricos de la trama de espionaje de los años cuarenta y cincuenta con la ficticia historia de Noah Volpi y su esposa. Por otro, contribuyen a relacionar esta historia con el relato autobiográfico de J. Volpi que - amén de sus pesquisas - narra sus aventuras conyugales y eróticas y la veloz formación financiera que lo condujo a fundar su propio hedge fund tras un eficaz aprendizaje de la especulación financiera de alto riesgo en el banco J. P. Morgan. De excepcional procedencia en el conjunto, puesto que se trata de una reciente foto de prensa integrada como fotograma en la película documental de Charles Ferguson, Inside Job, que investiga la crisis financiera de 2008, una imagen casi crea un efecto de actualidad al inscribir visualmente las tribulaciones profesionales de J. Volpi en el marco referencial real de la historia económica inmediata. Memorial del engaño se acerca no al documental, sino al género del docudrama, cuando no al del mockmentary o a su equivalente texto-visual en la crónica. Junto a su ambivalente función ficticia documental, las fotos, al igual que la del supuesto autor, encarecen aún el propósito satírico de la novela, al inscribirla en una resuelta y doble estrategia paródica. Por un lado, su escansión del relato parodia la vulgarización mediática texto-visual que impera en ciertos reportajes de prensa o en algunos volúmenes de periodismo de investigación que tratan de los escándalos y las crisis financieras o los casos de espionaje, corrupción y malversaciones de fondos. Por otro, se insertan, curiosa e inverosímilmente, en un ficticio relato autobiográfico que remeda los muy comerciales libros de escandalosas confidencias o revelaciones que firman diversas figuras públicas, o que se vuelven tales, a favor de alguna actualidad mediática.

Desde luego, el ilustrado relato de Memorial del engaño reivindica el arte de la novela como falsificación o lúdica mentira verdadera ante las totales mentiras de la desinformación o las mentiras a medias de la información texto-visual que tanto deben al manejo de la imagen fotográfica. Estafador y mentiroso su autor apócrifo; resuelto, lúdico e insistente falsario su autor auténtico, Memorial del engaño asimila las dos figuras en una estrategia que finge cuestionar irónicamente, en un registro pop mediático a priori alejado del que maneja A pesar de la oscura sombra, la identidad, más allá de la de un tal Jorge Volpi, de todo autor. En ambos casos, sin embargo, se enuncia y se muestra que el retrato fotográfico de autor impreso en el libro solo certifica que existió un sujeto fotografiado del que se afirma que es el autor de la obra. La relación de cita visual entre los dos retratos de $A$ pesar del oscuro silencio desrealiza el de Jorge Volpi y afirma su devenir personaje. El retrato de Memorial del engaño fabrica un autor-personaje de la ficticia autobiografía. En ambos casos, al manipularse la imagen del autor, sea o 
no apócrifa, para vincularla con el texto de la ficción, se subraya que la fotografía de autor impresa en cualquier libro lo torna ser de papel.

\section{Biografía de un escritor apócrifo y archivo documental}

Si puede atribuírsele a Shiki Nagaoka: una nariz de ficción, al igual que a otras obras de Bellatin, un discurso de sesgada autobiografía o autocrítica literaria, la novela acude, en una estilización paródica y minimalista, a los gestos y estrategias propias de la biografía de escritor - el ficticio japonés Shiki Nagaoka, dotado de un descomunal apéndice nasal, y contemporáneo del real Junichiro Tanizaki-. La ficción se dota a su vez de un consecuente apéndice al completarse el relato biográfico, como paródica garantía de la realidad del biografiado, con el arriba mencionado y profuso archivo fotográfico seudodocumental que forma parte de sus anexos. Por la tópica lejanía cultural y temporal del universo ficcionalizado, el archivo de fotos en blanco y negro acompañadas con sendas leyendas cobra un ostensible carácter etnográfico y museográfico, vaga y cómicamente obsoleto. Entre las fotos del anexo, todas descontextualizadas y recontextualizadas, algunas pretenden reconstituir el entorno material del ficticio escritor - sus peculiares utensilios de tocador, sus lugares de residencia, el mapa de su barrio rebautizado como Barrio de la Nariz, etc.- , otras representan sus obras, otras más los distantes lugares -París, Tepoztlán-, donde se intenta interpretarlas, otras más son supuestos retratos del biografiado y de sus familiares.

En el caso de los retratos apócrifos de Shiki Nagaoka, uno lo representa a la distancia, en compañía del deforme sirviente que fuera el reacio objeto de su deseo. La foto, intencionadamente oscura y borrosa, solo permite discernir las dos figuras cuyos rostros apenas resultan visibles. La leyenda del otro, un perfil del rostro del escritor, que también aparece en la portada de la primera edición, señala que la foto fue intencionadamente manipulada por la hermana y albacea de la obra de Shiki Nagaoka, para que no se le confundiera con un personaje de ficción. Tal manipulación consistió en borrar mediante una sobreexposición el mayor rasgo distintivo de su físico, su nariz. La leyenda - en este, como en otros casos - prolonga directamente lo narrado en el relato biográfico, que así empieza: "Lo extraño del físico de Shiki Nagaoka, evidenciado en la presencia de una nariz descomunal, hizo que fuera considerado un personaje de ficción" (Bellatin, Shiki Nagaoka 11). Jugando todo el relato fototextual con un constante revertirse de los efectos ficcionalizantes y los codificados efectos de realidad, cómica e irónicamente subrayados, plantea desde un inicio la equivalencia para el vulgo, casi paronomástica en el texto por lo demás, entre físico - extraño- y ficción. No es así de sorprender que el conjunto ficticio acuda a una actualización texto-visual 
del principio literario del extrañamiento caro al formalista ruso Víctor Shklovski, al volver extraño lo común, ciertamente, y a la vez, al volver común o creíble lo extraño. El juego metaliterario de la novela estriba en parte en la relación que abre entre las referidas búsquedas estéticas del escritor personaje y su propio, modesto e ironizado intento de completar la narración biográfica textual con una narración fotográfica documental.

Así, la triple interrogación que la obra literaria de Shiki Nagaoka dirige a las posibilidades del arte de escribir vierte sobre las relaciones entre lenguaje, fotografía y literatura. La primera se resuelve con un radical extrañamiento del lenguaje literario al resultar sus obras fruto de una traducción original: escritas en otro idioma, se traducen luego al japonés, sin que por ello el escritor deje de inscribirlas en los más tradicionales géneros y formas de la literatura japonesa, a diferencia de lo que, en aquel entreguerras mundiales, suelen hacer sus compatriotas. La segunda se resuelve al cabo, siendo Shiki Nagaoka el modesto y casi marginal dueño de un kiosco fotográfico, con la escritura de un libro, Foto y palabra, que hace escuela en el mundo tras la segunda guerra mundial. Su éxito se debe a que la narración logra plasmar la realidad del Japón de la época, al describir con falsa y minuciosa inocencia una serie de fotos que registran aspectos de la vida cotidiana. La tercera y más audaz experimentación literaria del escritor consiste en escribir un libro en un idioma de su invención, obra esta que afianza el culto internacional del escritor y despierta los más fervorosos intentos de desciframiento entre los especialistas. Tanto el final del relato textual de la novela como la última foto del anexo documental dejan entrever el posible éxito interpretativo de este libro por parte de "cierto escritor mexicano"; mientras la bibliografía secundaria en anexo menciona el correspondiente y apócrifo ensayo del mexicano y muy real Pablo Soler Frost, efectivamente residente a la sazón en Tepoztlán. El libro relataría un atroz crimen pasional, cuya ejecución habría encargado Shiki Nagaoka desde su reclusión en un monasterio debida a la denuncia por acoso sexual del sirviente deforme, ahora occiso. La cruel comicidad de los motivos biográficos relacionados con la vida erótica de Shiki Nagaoka alcanza ahí un clímax, al vincular el gesto críptico de la obra literaria con la banal ocultación de un crimen.

Desde luego, el obvio carácter bufo de tales motivos biográficos acentúa la broma generalizada que practica el relato, al proponer un simulacro de escritor como realidad histórica y al burlar todos los sólitos recursos de garantía de lo verídico, incluidos los documentos fotográficos. Sin embargo, objetos asimismo de broma, los experimentos estético-literarios del biografiado, que condensan varias búsquedas teóricas y creativas del siglo XX, entre ellos una forma de fotoliteratura, apuntan todos a aquellos efectos artísticos de extrañamiento que 
busca el propio Mario Bellatin, el tan plástico autor de Shiki Nagaoka, cuyas bromas literarias siempre encubren un riguroso y subversivo trabajo de creación. La ficción emprende así un solapado trabajo teórico que desestabiliza tanto las categorías de lo real como los codificados recursos de la expresión literaria, interrogando asimismo los tópicos de la crítica, la historia y la teoría literarias. Shiki Nagaoka, el personaje, y Shiki Nagaoka, el libro, emprenden así una crítica de las nociones de tradición e innovación, literatura nacional y literatura extranjera, margen y centro. El uso en la novela del archivo fotográfico de fines documentales, si bien ilustrativo de las estrategias de Bellatin para desemboscar falsos recursos de extrañamiento y activarlos irónicamente para volverlos eficaces, no deja de ser uno, tal vez esencial, entre los varios juegos prácticos de la ficción, divertida y artísticamente teórica.

\section{Lo real ficticio: relato de ficción y anexo fotográfico ready-made}

Perros héroes, breve relato fragmentario, no narra la vida de un apócrifo escritor japonés, sino la de un hombre cuya peculiaridad física se traduce en la perífrasis "el hombre inmóvil", que lo designa a lo largo del relato y cuya circunscrita fama se debe a su pericia en la crianza y el entrenamiento de los perros de raza pastor belga malinois. A su vez, el protagonista mantiene relaciones afectivas y, al parecer, sexuales con su enfermero y entrenador de perros. La implacable tiranía doméstica que ejerce, a base de chantajes y caprichos, sobre este, su madre y su hermana, solo se compara con la exactitud y precisión con que logra entrenar a sus perros. De nuevo, la cruel comicidad del relato sirve al motivo, falsamente lateral e incongruente, de la comparación entre el desquiciado régimen de poder que impone el adulto desde su postura de omnipotencia infantil, y el futuro de América Latina que, a decir del narrador, intuyen algunos visitantes al ingresar en el cuarto del protagonista. Futuro que una ulterior descripción sugiere como legible en un mapa del subcontinente donde queda señalada la ubicación de los mejores centros de entrenamiento de los pastor belga malinois. Numerosas aunque escuetas descripciones de la casa y el patio dan cuenta de la extrañeza de aquel opresivo universo doméstico: patio lleno de jaulas para los perros, cuarto y baño colmados de objetos fetiches pop y de algunos animales enjaulados o amarrados, entre los que destaca un halcón. El obsesivo y vano deseo de poseer una máquina de escribir, similar a la que tuvo un niño a quien conoció y que escribía sobre perros, relaciona al "hombre inmóvil" con la imposibilidad de la escritura y con otros textos de Mario Bellatin que evocan una y otra vez el primer libro del narrador mario bellatin, así como su primera máquina de escribir, una Underwood portátil: modelo 1915. A los diez años, relata Underwood portátil. 
Modelo 1915, el narrador escribió su primer libro que vertía sobre perros héroes cuyas imágenes recortaba y pegaba en un cuaderno. Perros héroes repite el gesto sesgadamente autobiográfico o autoficcional de Shiki Nagaoka, así como los temas y motivos que suelen manejar las ficciones de Bellatin - la discapacidad o deformación física, el encantamiento fetichista con determinados objetos, la colección de animales e imágenes de animales, el deseo de escribir y el de hacer libros, por ejemplo-. Y de hacerlos con imágenes.

Con sus fotos a color de estética amateur que remiten a todas luces al universo doméstico del "hombre inmóvil" descrito en el relato, el anexo fotográfico de Perros héroes parece declinar con otros recursos y mayor autoría en relación con las imágenes reunidas una remota actividad artística infantil. Al designar cada una de las fotos como registro de la serie de instalaciones "perros héroes", el libro del narrador y, aquí, el fotógrafo Mario Bellatin, por un lado, desvincula los elementos del lugar fotografiado de toda realidad previa, ficcionalizando su referente en coherencia con el carácter ficticio del relato; por el otro, reivindica la instalación del cuaderno fotográfico en el libro, aunque en esta ocasión se trata de un cuaderno autónomo. El gesto artístico se corresponde con el de un auténtico ready-made, de inspiración duchampiana, solo que combinado con el concepto de instalación, heredero de hecho de los originales ready-mades. Espacios y objetos fotografiados se declaran intencionadamente dispuestos, cuando solo el gesto del fotógrafo y su ulterior declaración de que las imágenes registran lo instalado los significa como realizaciones artísticas. Se alcanza así un clímax en la ficcionalización fotográfica de lo real y lo material, reafirmándose de paso sencillas y obvias verdades: el que el encuadre de una foto interpreta lo real fotografiado al seleccionarlo en la realidad, el que un conjunto de objetos fotografiados puede resultar de una intencionada escenificación o de su disposición artística en dado espacio.

Así, el cuaderno fotográfico de Perros héroes insinúa, en una suerte de recíproco contagio entre texto e imágenes fotográficas, que el correspondiente relato de ficción tan solo podría disponer elementos de la realidad de modo artístico, por lo que el lector llega a la sintética ilusión de que el libro llegó a expresar algo que podría llamarse lo real ficticio o, mejor aún, lo real artístico.

Tradicionalmente, la imagen fotográfica parecería certificar que en otra parte y en otro tiempo tuvieron presencia y existencia material aquellos cuerpos, rostros y objetos que registra. Si bien casi todas las obras leídas aquí interrogan los relatos biográficos o autobiográficos - convencionalmente asociados con lo real-y apuntalan la ficción, prolongándola, mediante los usos diversos y, en ocasiones, 
verdaderamente narrativos, literarios, al cabo, que hacen de la fotografía, es de notarse que con estos fines la foto, discreta o paródicamente desviada de su manejo como certificado de realidad, cualquiera que haya podido ser su eventual y original índole documental, convierte lo referencial real en referencia ficticia. Varias entre estas obras de Pauls, Volpi y Bellatin recurren a la imagen fotográfica para subrayar el devenir ficcional del autor real, o para insistir paródicamente en el carácter apócrifo de un supuesto autor del texto o de un ficticio personaje de escritor dado por real. Junto con el relato, el retrato fotográfico del autor o el del escritor biografiado media entre lo referencial real de la historia literaria y lo referencial imaginario de otra posible historia literaria. Así la relación texto-visual que manejan tanto las novelas de Jorge Volpi y de Mario Bellatin como el ensayo autobiográfico de Alan Pauls participa de refinados efectos metaliterarios y metaficcionales. Y el entredós entre lo legible y lo visible reduplica y potencia otras distancias internas del relato, textuales, propiciadas por la hibridez dinámica que entreteje los lábiles géneros convocados en cada una de las obras.

\section{Obras citadas}

Barthes, Roland. La chambre claire: note sur la photographie. Paris:

Cahiers du Cinéma/Gallimard/Seuil, 1980. Impreso.

Bellatin, Mario. Perros héroes. México: Alfaguara, 2006. Impreso.

Bellatin, Mario. Shiki Nagaoka: una nariz de ficción. Buenos

Aires: Sudamericana, 2001. Impreso.

Bellatin, Mario. "Underwood portátil. Modelo 1915". Obra reunida. México: Alfaguara, 2005 - 499-522. Impreso.

Camenen, Gersende. "Les étranges texte-images de Mario Bellatin: Fiction biographique et photographie". Actes du colloque "Photolittérature, littérature visuelle et nouvelles textualités". Eds. Paul Edwards, Vincent Lavoie, JeanPierre Montier. NYU, Paris, 26 y 27 de octubre 2012. Web. 25 de enero de 2015.

Camenen, Gersende. "Photographie et image de soi: La vie pieds-nus d'Alan Pauls". Actes du colloque "Le regard à l'œuvre. Lecteurs de l'image, spectateurs du texte. Eds. Teresa Orecchia-Havas, Anne Surgers, Marie-José Tramuta, Baptiste Villenave y Julie Wolkenstein, 26 de marzo de 2014. Web. 25 de enero de 2015.

Collomb, Michel. "Le défi de l'incomparable: Pour une étude des interactions entre littérature et photographie". Web. 15 de enero de 2015.

Edwards, Paul. Soleil noir: photographie et littérature des origines au surréalisme. Rennes: Presses Universitaires de Rennes, 2008. Impreso.

Goldchuk, Graciela. "Lecciones de realismo para una liebre muerta (sobre la obra de Mario Bellatin)". Documento procedente del Simposio 
Internacional Imágenes y Realismos en América Latina, Universidad de Leiden, 29 de septiembre a $1^{\circ}$ de octubre de 2011. Impreso.

Inside fob. Dir. Charles H. Ferguson. Culver City, Calif.: Sony Pictures Home Entertainment, 2011. Filme.

Louette, Jean-François y Roger Yves-Roche, eds. Portraits de l'écrivain contemporain. Seyssel: Champ Vallon, 2003. Impreso.

Méaux, Danièle, comp. Études romanesques 10. Número especial "Photographie et romanesque". Caen: Lettres Modernes Minard, 2006. Impreso.

Pauls, Alan. La vida descalzo. Buenos Aires: Sudamericana, 2006. Impreso.

Volpi, Jorge. A pesar del oscuro silencio. México: Joaquín Mortiz-Planeta, 1992. Impreso.

Volpi, Jorge. En busca de Klingsor. Barcelona: Seix Barral, 1999. Impreso.

Volpi, Jorge. El fin de la locura. Barcelona: Seix Barral, 2003. Impreso.

Volpi, Jorge. "El magisterio de Jorge Cuesta". Plural 234 (1991): 26-40. Impreso.

Volpi, Jorge. Memorial del engaño. México: Alfaguara, 2013. Impreso. 